\title{
Organizational-Based Self-Esteem and Organizational Identification as Predictors of Turnover Intention: Mediating Role of Organizational Trust
}

\author{
Tochukwu Matthew Oguegbe ${ }^{1}$, Henry Samuel Edosomwan ${ }^{{ }^{*}}$ \\ 1, 2Department of Psychology, Nnamdi Azikiwe University, Awka, Anambra State, \\ Nigeria \\ * Corresponding author: edosomwanofficial@gmail.com
}

\begin{abstract}
Article History
Received 2021-03-25

Revised 2021-04-03

Accepted 2021-04-04

Published 2021-04-04
\end{abstract}

\section{Keywords}

Organizational-based self-esteem

Organizational identification

Turnover intention

Organizational trust

\section{How to cite?}

Oguegbe, T. M., \&Edosomwan, H. S. (2021). Organizational-Based Self-Esteem and Organizational Identification as Predictors of Turnover Intention: Mediating Role of Organizational Trust.

SEISENSE Journal of Management, 4(2), 56-71. doi:

$10.33215 /$ sjom.v4i2.620
Abstract

Purpose- This study aimed to examine the predictive role of organizational-based self-esteem and organizational identification on turnover intention while also studying the mediating effect of organizational trust among employees across five organizations.

Design/Methodology- This study utilized the cross-sectional research design and quantitative approach for data collection. The study sample comprises 131 employees drawn from five organizations with a mean age of 33.15 years (SD, 7.97). Standardized instruments (questionnaires) were used for data collection. The IBM-SPSS Statistics and Hayes PROCESS macro (model 4) was used for testing the hypotheses and conducting the mediational analysis.

Findings- The results of the study revealed a significant negative relationship between organizational-based self-esteem and turnover intention $(\beta=-.33, p<.01)$, and also a significant negative relationship between organizational identification and turnover intention $(\beta=-.29, \mathrm{p}<.01)$. Organizational trust was also found to mediate both relationships.

Practical Implications- The results of this study highlight the importance of organizational-based self-esteem, organizational identification and trust in reducing turnover intention. The study recommends that to keep employees in the organization, human resources management (HRM) needs to foster trust, build practice that will promote identification and attachment, and enhance the relationship between the organization and employees. 


\section{Introduction}

Organizational-based self-esteem, organizational identification, turnover intention, and trust in the organization are recurring topics in management literature. It is well established that the human capital in the organization remains an essential factor to consider in achieving organizational success, which is the goal of organizations worldwide (Valenti \& Horner, 2019). Retaining the best talents in the organization has been one of the major ways of attaining this success. Organizations worldwide are designing retention strategies to help them optimize the human resource at their disposal (Kaur \& Mohindru, 2013). Irrespective of this, some employees still consider leaving the organization, which can be attributed to various factors (including individual and organizational). Turnover is a very crucial issue for all organizations. Turnover is defined as the degree to which existing employees leave and new employees come into the organization (Kaur \& Mohindru, 2013). Turnover is categorized into a voluntary and involuntary turnover. It is voluntary when employees leave the organization out of their choice or freewill.

On the other hand, it is involuntary when the organization decides to terminate the employment relationship or do away with an employee. Voluntary turnover, which is the main focus of this study, has dire consequences for the organization. Turnover intention is the likelihood that an employee will leave the organization within a given time (Cotton \& Tuttle, 1986; Seo \& Ko, 2002).

Literature on the likely individual and organizational factors that can predict employee turnover intention is complex and ongoing. In this study, organizational-based self-esteem and organizational identification are utilized as predictors of turnover intention while also studying for the mediating effect of organizational trust. Although few studies have been carried out on the relationship between the independent variables (Organizational-based self-esteem and organizational identification) and turnover intention, the current study is necessitated by some gap in the literature. First, the literature is highly dominated by studies conducted in Europe and America (e.g., Bowden, 2002; Cole \& Bruch, 2006; Giritli, 2015; Phillips \& Hall, 2001; Van Dick et al., 2004). Therefore, the current study presents research from a different cultural setting, which may have an impact on the instruments for data collection, conceptualization, and the possible relationship between the independent and dependent variables (McArthur, 2007). Second, studies on the relationship between turnover intention and other organizational variables carriedout in the present research location (Nigeria) have primarily focused on private-sector employees (e.g., Chiedu, Long, \& Ashar, 2017; Mbah \& Ikemefuna, 2012; Umar \& Ringim, 2015) with little attention given to the public sector employees. The current study utilized employees in public and private sector organizations offering the research findings a broader application and strength of generalization. Lastly, it is well established in organizational research that another variable can mediate the relationship between two variables. The current study also included a possible mediating variable (organizational trust) better to understand the relationship between independent and turnover intention. Theoretical evidence (social exchange theory; Blau, 1964) supported the inclusion of organizational trust as a mediator in this study. The importance of establishing trust in the employee-employer relationship cannot be undermined. Trust between individuals and groups within the organization has been recognized as a very important tool in achieving long-term stability in the organization and dealing with the welfare of its members (Cook \& Wall, 1980).

Because of the above-stated problem and research gap, the study aims to examine the predictive role of organizational-based self-esteem and organizational identification on turnover intention and investigate the mediating role of organizational trust on the observed relationship predictors and the criterion variable. 


\section{Conceptual Review}

\section{Organizational-Based Self-Esteem}

The importance of employee workplace behavior cannot be overemphasized. Organizational-based self-esteem is one of the behaviors that are likely to have an impact on other organizational processes. Organizational-based self-esteem is defined as the extent to which employees believe they are essential, meaningful, effectual, and worthwhile within the organization they work for (Pierce et al., 1989). This construct has been given much attention in behavioral research (e.g., Chan et al., 2013; Gardner \& Pierce, 2011; Kark \& Shamir, 2002). Organizational-based self-esteem is an employee's overall evaluation of his/her capability, worthiness, and importance as a member within the organizational setting (Pierce \& Gardner, 2004). This worth that employees build is based on the history of interpersonal and systemic experiences (Pierce et al., 1989).

\section{Organizational Identification}

Several definitions have been proposed for organizational identification. Organizational identification is defined as the employee's perception of oneness with and belongingness to the organization in which they are a member (Ashforth \& Mael, 1989). The congruence of individual and organizational values is essential in identifying with an organization (Pratt, 1998; Stengel, 1987). Organizational identification can also refer to how an employee integrates the self-perception as a member of a specific organization into a general self-definition (Dutton et al., 1994; Rousseau, 1998). Organizational identification consists of oneness with the organization, showing support for the organizational processes, and having common characteristics with other members of the organization (Patchen, 1970). Organizational identification indicates the level of psychological attachment and feeling of belongingness an employee has for being a member of an organization. Social identity theory- which is the most prevalent theory used in explaining organizational identification, is of the notion that people from a perception of the self through interaction, affiliation, and connection to specific social groups, such identification helps in fostering and protecting self-identity (Carmeli, Gilat \& Waldman, 2007).

\section{Turnover Intention}

Turnover intention is the individual's intention to willingly leave the organization or end the employment relationship (Seo \& Ko, 2002). It is an employee's perception of the possibility of leaving the organization he/she works for (Cotton \& Tuttle, 1986). Turnover intention is a conscious process seen as a stage before the final decision to leave the organization. Many factors in the workplace interact before the employee makes the final decision to leave the organization. Turnover occurs in two ways: voluntary and involuntary turnover. Voluntary turnover occurs when an employee decides to terminate the employment relationship by leaving the organization. In contrast, involuntary turnover occurs when the organization decides to terminate the employment contract with the employee due to reasons including workplace misconduct (e.g., insubordination, dishonesty) and incompetence (e.g., poor job performance) in the workplace (Seo \& Ko, 2002). This study is focused on the interactions of other workplace variables (organizational-based self-esteem, organizational identification, and organizational trust) on voluntary turnover intention.

\section{Organizational Trust}

Organizational trust is a type of institutional trust built mainly on the relationship between employees, supervisors, and the organization (Ashford, Lee, \& Bobko, 1989). In an attempt to integrate all essential components of trust based on the different approaches used to investigate the concept in organizations, Mayer, Davis, and Schoorman (1995) defined organizational trust as the willingness of an employee to be susceptible to the actions of the organization based on the belief and expectation that the organization will carry-out specific step important to him/her, regardless of his/her ability to assert control or monitor the organization. According to Bhattacharya, Devinney, and Pillutla (1998), trust is an expectancy of positive outcomes that an individual 
can get based on another party's expected action, which is characterized by uncertainty. This suggests that organizational trust is mainly dependent on interaction, vulnerability, anticipation, and expectation.

Several existing definitions of the concept of trust was merged by Whitener et al. (1998), and this led to three essential facets of trust: (a) trust in another party reflects an expectation that the other party will act benevolently; (b) neither party can force or control the other to fulfill the expectations involved, and (c) Some level of dependency is built on the other party such that the outcome of one party affects the actions of another. Organizational trust refers to the employees estimating and identifying with organizational policies and being willing to expose themselves to be hurt in a job situation (Robinson, 1996). In line with this, trust involves the willingness to take the risk and be vulnerable to another party, believing that the party will live up to its expectations (Lamsa \& Pucetaite, 2006). Thus, organizational trust involves a set of beliefs and expectations as perceived by the employees that the actions of the organization will be beneficial to their long-term self-interest and goals, especially in situations in which the employees depend on the organization to make provisions for things that are significant to promoting employees' wellbeing and approach to work. The current study defines organizational trust as the total evaluation of the organization's trustworthiness as perceived by the employees, i.e., organizational trust is the employee feeling of confidence in the organizational processes, belief that the organization will perform actions that are rewarding and beneficial, or at least not detrimental to him or her (Tan \& Tan, 2000).

\section{Hypothesis Development}

\section{Organizational-Based Self-Esteem and Turnover Intention}

The empirical literature has established that organizational-based self-esteem positively impacts other workrelated behaviors that are significant to the success of an organization. For example, organizational-based selfesteem has been found to correlate positively with job and general workplace satisfaction (e.g., Pierce et al., 1989; Carson et al., 1998; Bowden, 2002; Gardner \& Pierce, 2001; Van Dyne \& Pierce, 2004), organizational identification (e.g., Bowden, 2002; Kark \& Shamir, 2002), adaptation to organizational change (Staehle-Moody, 1998), facets of organizational citizenship behavior- altruism and compliance (Tang \& Ibrahim, 1998), selfperceived employability (Sumanasiri, Ab Yajid \& Khatibi, 2016) and organizational commitment (e.g., Pierce et al., 1989; Phillips \& Hall, 2001; Tang, Singer \& Roberts, 2000; Van Dyne \& Pierce, 2004) indicating that employee with high organizational-based self-esteem is more committed to the organization. This suggests that organizational-based self-esteem has a positive impact on good workplace behaviors. Therefore, it should be able to reduce negative workplace behavior among employees in an organization.

Therefore it is not surprising that organizational-based self-esteem has an empirical link with employee turnover intention. Existing literature indicates that organizational-based self-esteem correlates negatively with turnover intentions (e.g., Bowden, 2002; Gardner \& Pierce, 2001; Phillips \& Hall, 2001). More recently, Hardaningtyas (2020) studied the mediating role of work engagement on the predictive relationship between personal resources (self-efficacy, organizational-based self-esteem, and optimism) and turnover intention and observed that personal resources (self-efficacy, organizational-based self-esteem, and optimism) have a positive effect on turnover intention and that work engagement mediated this relationship. The outcome of organizational-based self-esteem reduces turnover intentions. In congruence with the above review, it is hypothesized that:

Hypothesis One (H1): Organizational-based self-esteem (OBSE) has a negative predictive relationship with turnover intention.

\section{Organizational Identification and Turnover Intention}

Management literature has paid considerable attention to organizational identification and turnover intention across various work settings. The construct of Organizational identification can effectively influence an employee's decision to leave or remain in an organization. For instance, organizational identification was found 
to have a significant adverse effect on turnover intention (e.g., Cole \& Bruch, 2006; Giritli, 2015; Hameed, Arain, \& Farooq, 2013; Kumar \& Singh, 2012; Van Dick et al., 2004). Meta-analytical studies have also reported a strong negative correlation between organizational identification and turnover intention (e.g., Meyer et al., 2002; Riketta, 2005; Zang \& Liu, 2016). Chi, Friedman, and Lo (2010) went further by investigating the downside of organizational identification during a period of collective shame and the impact on employee turnover intention. The result of their study indicated that employees who make solid internal attributions for the organization's wrong actions were more likely to feel collective shame and guilt-collective shame leads to an increase in turnover intention- therefore, more likely to leave the organization. This indicates that organizational identification may harm the organization during a period of organizational wrongdoing. Based on the review above, it is hypothesized that:

\section{Hypothesis Two (H2): Organizational identification has a negative predictive relationship with turnover intention.}

\section{Organizational Trust as a Mediator}

Over the years, management researchers have explored the predictive relationship between variables by utilizing mediation and moderation analysis. Evidence linking organizational trust to increase desirable workplace behaviors exists in the literature. For example, organizational trust is a critical factor in organizational effectiveness (Siebert et al., 2015), cooperative behavior (Gambetta, 1998), employee engagement (Ugwu et al., 2014), affective commitment (Xiong et al., 2016), organizational citizenship behavior (Chhetri, 2014) and job satisfaction (Aryee, Budhwar, \& Chen, 2002). Organizational trust has also been found to reduce negative workplace behavior such as counterproductive work behavior (Ran \& Wang, 2010), deviant organizational behavior (Akhigbe \& Sunday, 2017; Baghini, Pourkiani, \& Abbasi, 2014; Celik, Turunc, \& Begenirbas, 2011) and turnover intention (Balkan, Serin, \& Soran, 2014; Davies et al., 2000).

The ability of the organizational trust to reduce negative workplace behavior might indicate that it can mediate the role of organizational-based self-esteem and organizational identification on turnover intention. Literature on the mediating role of organizational trust between the independent variables (organizational-based selfesteem and organizational identification) and turnover intention is in shortage. Few studies on the mediating role of organizational trust on the relationship between other organizational variables exist. For example, organizational trust has been found to partially mediate the relationship between organizational justice and organizational commitment (Iqbal \& Ahmad, 2016), perceived organizational support and constructive deviance (Kura, Shamsudin, \& Chauhan, 2016), specific areas of work-life (workload, fairness, reward, and value), and emotional exhaustion (Bayhan, Metin, \& Tayfur, 2016), psychological empowerment, job satisfaction and organizational commitment (Alajmi, 2016), distributive and procedural justice on turnover intention (Aryee, Budhwar, \& Chen, 2002) and employee- organizational relationship and innovative work behavior (Yu et al., 2018). A study by Hameed, Arain, \& Farooq (2013) on the mediating role of identity-based trust on the relationship between organizational identification and turnover intention indicated that trust partially mediated the negative relationship between the predictor and criterion variable.

Organization trust as a mediator between the independent variables (organizational-based self-esteem and organizational identification) and turnover intention can be explained by social exchange theory. Social exchange theory based on reciprocity (Blau, 1964) suggests that employees are likely to return good organizational good deeds through positive behavior in the workplace. Thus, according to Blau (1964), the relationship between individuals and their work environment is based on two forms of exchange: transactional (which involves the exchange of money and related resources) and socio-emotional exchange (which consists of the way organizational treats employees and employee trust for the organization). Utilizing the exchange relationship's socio-emotional aspect, when employees perceive the organization as trustworthy (having the confidence that the organization's actions will be beneficial), employees tend to reciprocate through positive 
organization behavior such as deciding to remain a member of the organization. In sum, it is expected that organizational trust has a role in the relationship between the independent variables (organizational-based selfesteem and organizational identification) and turnover intention. Considering the review above, it is hypothesized that:

Hypothesis Three (H3): organizational trust mediates the negative relationship between (a) Organizational-based self-esteem (OBSE) and turnover intention, and (b) Organizational identification and turnover intention.

Based on the conceptual and empirical literature reviewed, the framework below has been designed for this study:

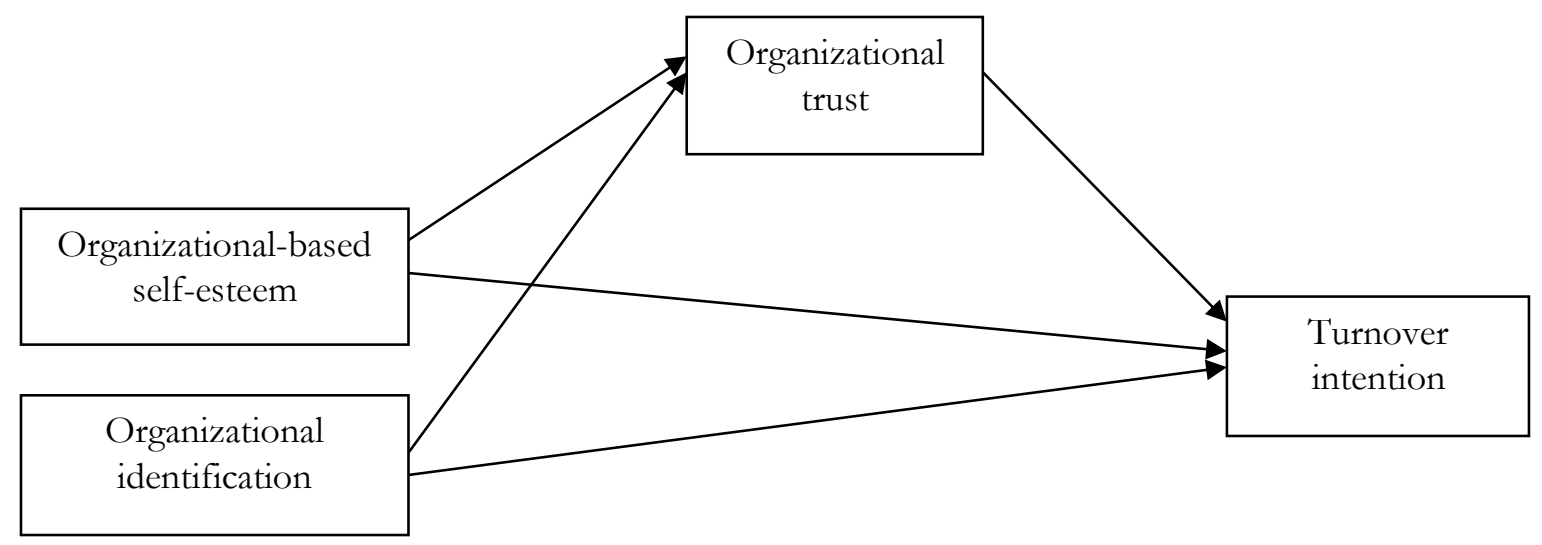

Fig. 1: Conceptual framework depicting the relationship between the variables.

\section{Methodology}

\section{Sample}

One hundred and thirty-one participants were sampled from five organizations in Lagos State, Nigeria. The participants' selected demographic characteristics represent some of the salient features used in categorizing employees in the workplace. According to the analysis of demographic characteristics, these features were well represented in the sample. The sample consists of $74(56.5 \%)$ males and $57(43.5 \%)$ females; $70(53.4 \%)$ unmarried and 61(46.6\%) married; 64(48.9\%) participants were from the privately-owned organization while $67(51.1 \%)$ participants were from government-owned organizations; $82(62.6 \%)$ were junior staff while $49(37.4 \%)$ were senior staff in the various organizations. The age range of the respondents was between 20-56, with a mean of 33.15 years (SD, 7.97years; Range, 36). All the participants had a formal education with a minimum of O' Level certification which accounted for 15(11.5\%). The majority city of the respondents, $102(77.9 \%)$, had a first-degree certification which gives validity to the use of report measures, accounted for the efficient response to the scale items, the questionnaires' high return retires. The inclusion criteria indicated that participants have spent between 3-27years in their respective organizations with a mean of 7.36 (SD, 5.24; Range, 24). A large proportion, consisting of $46(35.1 \%)$ of the research participants, have spent at least three years in their respective organizations.

\section{Procedure}

The researchers sought the permission of the five organizations before the administration of the questionnaires. The questionnaires were administered to participants in their workplaces through the assistance of line managers, supervisors, and senior administrators. To effectively measure these behaviors in the organizations, an inclusion criterion was developed. Only employees who have spent at least three years in their respective 
organizations were allowed to participate in the study. This is based on the assumption that three years is sufficient for an employee to develop specific behaviors towards the organization. Within this time frame, employees must have undergone different training and development programs, had various interactions with other employees in the organization (including staff at the human resource management level), and must have developed a unique attitude and perception of activities in the organization. A non-probability sampling (convenience sampling) technique was utilized in administering the questionnaires. It is a convenience sampling because employees who were available, easy to reach, and met the inclusion criteria was utilized for the study. One hundred and forty-five (145) questionnaires were distributed across all five organizations within four weeks. A total of $136(93.80 \%)$ questionnaires were retrieved. The response rate was largely satisfactory. However, after sorting out the questionnaire, 131(90.34\%) were used to analyze data.

\section{Measures}

\section{Organizational-based self-esteem:}

Organizational-based self-esteem was measured with a scale developed by Pierce et al. (1989). It is a 10-item scale measuring the degree to which employees believe they are worthwhile and valuable to the organization. A 5-point Likert-type scale ( $1=$ strongly disagree and $5=$ strongly agree) was adopted. Sample items for the scale include: "I am trusted in the organization I work for" and "I can make a difference in the organization I work for." The instrument's internal consistency (Cronbach's Alpha), as indicated by Pierce et al. (1989) with seven different samples, was between .89 and .96 with an average value of .91 .

\section{Organizational Identification:}

This was measured with the organizational identification scale developed by Mael and Ashforth (1992). It is a 6-item scale measuring the degree to which employees identify with their organization. A 5-point Likert-type scale $(1=$ strongly disagree and $5=$ strongly agree) was also adopted. Sample items for the scale include: "If a story in the media criticizes my organization, I would feel embarrassed" and "I am very interested in what others think about the organization I work for.” A Cronbach's alpha of .87 was reported for the 6-item scale (Mael \& Ashforth, 1992).

\section{Turnover Intention:}

The turnover intention was measured with a 4-item employee turnover intention scale developed by Kim et al. (1996). The response was on a 5 -point Likert format $(1=$ strongly disagree and $5=$ strongly agree). Two items were negatively worded. These negatively worded items were reversed coded. Sample items from the scale include: "I plan to leave my current organization as soon as possible" and "under no circumstances will I voluntarily leave my organization." A Cronbach's alpha of .85 was reported for the 4-item scale (Kim et al., 1996).

\section{Organizational Trust:}

The organizational trust scale developed by Robinson (1996) was utilized for this study. The organizational trust scale is a 7-item scale that measures employee feeling of confidence in the organizational processes and belief that the organization will perform actions that are rewarding and beneficial to them. A 5-point Likert type scale $(1=$ strongly disagree and $5=$ strongly agree) was utilized as indicated by the scale developer. Items 1,2 , 4, and 6 are positively worded, whereas items 3, 5, and 7 are negatively worded and reversed coded. Examples of some of the items are: "I believe my employee has high integrity" and "my employee is not always honest and faithful." Cronbach's alpha was reported across two surveys carried out within 30 months with the same scale. Survey one indicated a Cronbach's alpha of .82, and survey two indicated a Cronbach's alpha of .87 (Robinson, 1996). 


\section{Design and Statistical Tool}

This study adopted the cross-sectional research design. The cross-sectional research design is appropriate because the sample was drawn from all participating organizations, and data were collected from the sample at one point in time (Shaughnessery et al., 2003). Hypotheses 1 and 2 were tested with simple linear regression, while hypotheses $3 \mathrm{a}$ and $3 \mathrm{~b}$ were tested with the mediational analysis using PROCESS macro-a modeling tool designed for IBM-SPSS (Hayes, 2013). In establishing for a mediational effect using PROCESS macro, there has to be no absolute zero in the range between the boot lower limit and the boot upper limit confidence interval in the indirect effect, i.e., if zero is not included in the interval, mediation has been established (Hayes, 2013). All the conditions necessary for establishing mediation were strictly observed. For instance, the likert scale was used to establish interval scaling, while the scatter plot derived from the data showed a linear relationship between the variables in the study. IBM-SPSS Statistics version 24 and Hayes PROCESS macro (model 4) were utilized for the data analysis.

\section{Common Method Variance}

Common method variance is one of the shortcomings of a questionnaire-based study. To control for common method variance, the researcher employed some of the methods suggested in the literature during the design of the study. To control for respondents' misinterpretation of the scale items and random responses, the wording of the questionnaire was clear, concise, and easy for the respondents to understand. The cover later guaranteed the respondents' anonymity and stated that there are no correct or incorrect responses to help reduce the socially desirable responses. These methods were applied to increase respondents' honesty (Podsakoff et al., 2003; Steenkamp, de Jong \& Baumgartner, 2010; MacKenzie \& Podsakoff, 2012).

\section{Results}

\section{Reliability and Validity}

The Cronbach's alpha for all the scales is shown in table 1. The four scales utilized for collecting data were tested for reliability and validity. The internal consistency of the scales was achieved through Cronbach alpha. Cronbach alpha value of .87 was obtained for organizational-based self-esteem, .86 for organizational identification, .77 for turnover intention, and .88 for organizational trust. The Cronbach alpha values were satisfactory and indicated that the scales have high internal consistency. An internal consistency coefficient (Cronbach's alpha) of .70 or above is primarily considered satisfactory (Feldt \& Kim, 2008; Howitt \& Cramer, 2011). Content validity was achieved by adopting existing scales that have been used overtime and proven to be valid in other studies. The scales must have undergone the basic developmental stages of content validity as proposed by Lynn (1986).

Table 1: Reliability analyses of the variables

\begin{tabular}{lll}
\hline Variables & Number of Items & Cronbach's Alpha \\
\hline Organizational-based self-esteem & 10 & .87 \\
Organizational identification & 6 & .86 \\
Turnover intention & 4 & .77 \\
Organizational trust & 7 & .88
\end{tabular}

Test for normality using skewness and kurtosis, as shown in table 2 indicates that the values were within the normal range $(-3$ to +3$)$. This is an indication that the data is normally distributed (Gbasemi \& Zahediaal, 2012). 
Table 2: Test of normality using skewness and kurtosis

\begin{tabular}{lcccccc}
\hline & Skewness & $\mathrm{SE}_{\text {skewness }}$ & $\mathrm{Z}_{\text {skewness }}$ & Kurtosis & $\mathrm{SE}_{\text {kurtosis }}$ & $\mathrm{Z}_{\text {kurtosis }}$ \\
\hline OBSE & -.48 & .21 & -2.28 & -.42 & .42 & -1 \\
Org Identification & -.37 & .21 & -1.76 & -.26 & .42 & -.61 \\
Turnover Intention & .28 & .21 & 1.33 & -.20 & .42 & -.48 \\
Org Trust & .31 & .21 & 1.47 & -.04 & .42 & -.01
\end{tabular}

Note: $\mathrm{SE}_{\text {skewness }}=$ standard error of skewness, $\mathrm{SE}_{\text {kurtosis }}=$ standard error of Kurtosis, $\mathrm{Z}_{\text {skewness }}=\mathrm{z}$-score for skewness, $Z_{\text {kurtosis }}=\mathrm{z}$-score for kurtosis, OBSE= Organizational-based self-esteem, Org Identification= organizational identification, Org Trust= organizational trust.

The Durbin-Watson test was within the acceptable range. It ranged from 1.78-1.87 and was acceptable concerning autocorrelation. The tolerance statistics were above .02 , while the variance inflation factors (VIFs) were below ten, indicating an absence of multicollinearity (Field, 2013). Table 3 shows the mean, standard deviation, and correlation coefficient of the variables in the study. The table indicates that all the relationships are significant at $\mathrm{p}<0.01$. The highest correlation coefficient was between organizational trust and organizational-based self-esteem at $\mathrm{p}<0.01$. The observed Correlation coefficient was modestly indicating an absence of multicollinearity.

Table 3: Mean, standard deviation, and the correlation matrix on the variables

\begin{tabular}{lllllll}
\hline & Variables & $\mathbf{x}$ & SD & $\mathbf{1}$ & $\mathbf{2}$ & $\mathbf{3}$ \\
\hline 1 & Organizational- based self-esteem & 4.38 & .47 & & & \\
2 & Organizationalidentification & 4.27 & .67 & $.50^{* *}$ & & \\
3 & Turnover intention & 2.43 & .78 & $-.33^{* *}$ & $-.29^{* *}$ & \\
4 & Organizationaltrust & 3.90 & .64 & $.59^{* *}$ & $.57^{* *}$ & $-.57^{* *}$ \\
\hline
\end{tabular}

**p $<0.01$ level (two-tailed).

\section{Hypothesis Testing}

The hypotheses were tested with simple regression analysis, while the mediational analysis was carried out using Hayes PROCESS macro (Hayes, 2013). Conditions necessary for regression and mediational analysis were adhered to. Table 4 shows a simple linear regression analysis of organizational-based self-esteem and organizational identification on turnover intention. As indicated in the table, the relationship between organizational-based self-esteem and turnover intention was negative and significant $(\beta=-.33, p<0.01)$. The test for analysis of variance also indicated that the simple regression analysis was significant $(F=(1 ; 130)=15.86$, $\mathrm{p}<0.01)$ in predicting turnover intention. The $\mathrm{R}^{2}$ statistics indicated that organizational-based self-esteem accounted for an $11 \%$ variance in turnover intention. Based on Cohen's (1988) criterion, the $\mathrm{R}^{2}$ reflects a medium effect size. The $\mathrm{B}=-.55$ indicates that for every one-unit increase in organizational-based self-esteem, turnover intention reduces by 0.55 . The table also indicated a significant negative relationship between organizational identification and turnover intention $(\beta=-.29, \mathrm{p}<0.01)$. Analysis of variance test also showed a significant relationship $(\mathrm{F}=(1 ; 130)=11.55, \mathrm{p}<0.01)$ in predicting turnover intention. The $\mathrm{R}^{2}$ statistics indicated that organizational identification accounted for an $8 \%$ variance in turnover intention. Based on Cohen's (1988) criterion, the $\mathrm{R}^{2}$ reflects a medium effect size. The $\mathrm{B}=-.33$ indicates that for every one-unit increase in organizational-based self-esteem, turnover intention reduces by 0.33 . 
Table 4: Simple linear regression analysis of Organizational-based self-esteem and organizational identification on turnover intention

\begin{tabular}{|c|c|c|c|c|}
\hline & & $\begin{array}{l}\text { Organizational-based } \\
\text { esteem }\end{array}$ & self- & Organizational identification \\
\hline \multirow{5}{*}{ Turnover intention } & $B$ & -.55 & & -.33 \\
\hline & $S E$ & .14 & & .10 \\
\hline & $\beta$ & $-.33^{* *}$ & & $-.29 * *$ \\
\hline & $t$ & -3.90 & & -.3 .40 \\
\hline & Durbin- & 1.78 & & 1.87 \\
\hline \multirow[t]{2}{*}{ Watson } & & $(-.82,-.28)$ & & $(-.53,-.14)$ \\
\hline & $95 \% C I$ & $\begin{array}{l}\mathrm{F}(1 ; 130)=15.86, \mathrm{R}=.33 \\
\mathrm{R}^{2}=.11, \mathrm{p}<0.01\end{array}$ & & $\begin{array}{l}F \quad(1 ; 130)=11.55, \quad R=.29, \\
R^{2}=.08, p<0.01\end{array}$ \\
\hline
\end{tabular}

${ }_{* *}^{*}<0.01$ level (two-tailed).

Table 5 below shows the indirect effect of organizational-based self-esteem on turnover intention through its effect on organizational trust. Since absolute zero was not indicated in the range between the boot LLCI and boot ULCI indirect effect (boot LLCI $=-.85$, boot ULCI=-.32) mediation was established. The results indicated that organizational trust mediated the relationship between organizational-based self-esteem and turnover intention.

Table 5: Indirect effect of organizational trust on paths from organizational-based self-esteem to turnover intention

\begin{tabular}{lcclc}
\hline Mediator & Effect & Boot standard Error & \multicolumn{2}{l}{ Boot Confidence Interval } \\
\hline & & & BLLCI & BULCI \\
Organizational trust & -.57 & .13 & -.85 & -.32 \\
\hline Non
\end{tabular}

Note: BLLCI $=$ Boot Lower Limit Confidence Interval, BULCI = Boot Upper Limit Confidence Interval

Table 6 below shows the indirect effect of organizational identification on turnover intention through its effect on organizational trust. Since absolute zero was not included in the boot LLCI and boot ULCI indirect effect (boot LLCI=-.59, boot ULCI=-.24), mediation was established. The results indicated that organizational trust mediated the relationship between organizational identification and turnover intention.

Table 6: Indirect effect of organizational trust on patbs from organizational identification to turnover intention

\begin{tabular}{lcclc}
\hline Mediator & Effect & Boot standard Error & \multicolumn{2}{l}{ Boot confidence interval } \\
\hline & & & BLLCI & BULCI \\
\cline { 3 - 5 } Organizational trust &. .40 & .09 & -.59 & -.24 \\
\hline
\end{tabular}

Note: BLLCI $=$ Boot Lower Limit Confidence Interval, BULCI = Boot Upper Limit Confidence Interval

\section{Discussion}

The study was carried out to examine the role of organizational-based self-esteem (OBSE) and organizational identification on employee turnover intention and the mediating effect of organizational trust in the relationships. The model that organizational-based self-esteem negatively and significantly predicts turnover intention was good and offered support for hypothesis 1 . This result is consistent with the extant literature (e.g., Bowden, 2002; Gardner \& Pierce, 2001; Phillips \& Hall, 2001), indicating that as organizational-based selfesteem increases, turnover intention tends to decrease in the organization. The model that organizational 
identification negatively and significantly predicts turnover intention was also supported in this study, which supports hypothesis 2. This finding is congruent with the extant literature (e.g., Cole \& Bruch, 2006; Hameed, Arain, \& Farooq, 2013; Giritli, 2015; Kumar \& Singh, 2012; Van Dick et al., 2004; Riketta, 2005; Zang \& Liu, 2016) indicating that when employees identify with the organization, the chances that they will leave the organizational is reduced significantly.

The Mediational analysis established that organizational trust mediated the relationship between organizationalbased self-esteem and turnover intention as the indirect effect measured through PROCESS macro (Hayes, 2013) had no absolute zero in the range between the boot LLCI and boot ULCI giving support for hypothesis 3a. The employee's feeling of confidence in the organizational processes and belief that the organization will perform rewarding and beneficial actions play an important role in an employee's decision to leave or stay with the organization. Therefore, organizational trust and organizational-based self-esteem account for the observed reduction in employee turnover intention in this study. Lastly, the hypothesis that organizational trust will mediate the relationship between organizational identification and turnover intention was also supported (hypothesis 3b). The mediational analysis measured through PROCESS macro (Hayes, 2013) showed no absolute zero in the range between the boot LLCI and boot ULCI, indicating that mediation exists. Therefore, the relationship between organizational identification and turnover intention was mediated by Organizational trust. The results of both mediational analyses (organizational trust on hypothesis 1 and hypothesis 2) were consistent with the social exchange theory (Blau, 1964), which is built on the notion of reciprocity. Employees are likely to return good organizational deeds through positive behavior in the workplace. When trust is established between the organization and the employees, employees are likely to stay with the organization.

\section{Practical Implications}

As the extant literature and this study indicated, organizational-based self-esteem, organizational identification, and organizational trust are of great importance to employee turnover in the organization. Therefore, these factors have implications for management. For management to keep employees in the organization, some practices that can help build employees' esteem in the organization, identification, and trust need to be established and executed by human resources management. Some of these practices may include consistent communication with employees, being honest and truthful regarding what happens within the organization (e.g., appraising employees for promotion), treating employees in consistent and predictable manner, promoting wellbeing, etc.

\section{Limitations and Suggestions for Future Research}

Although the purpose for which the research was carried has been achieved, it is essential to point out the critical limitation that is likely to affect the interpretation of the research findings. The first limitation is the use of a cross-sectional research design. Since the study uses the cross-sectional research design, it wasn't easy to establish the cause-effect relationship. Further studies in this area should use longitudinal or field experimentation to establish cause-effect relationships among the study variables. Another major limitation of the study is the convenience sampling technique utilized in selecting participants. Further studies should use a probability sampling method.

Also, the self-report measure was the only research tool utilized for gathering data from the participants. Several steps were taken to help reduce method bias during the design of the study. Still, some social desirability factors remain since it is challenging to control in a survey. A possible suggestion for future studies would be to include items in the questionnaire that can help identify participants with these characteristics and exclude their responses from the final data used for analysis. 
Furthermore, public and private organizations were primarily represented in the sample. Still, the number of organizations utilized in the study affected the sample size, which may likely affect the generalization of the results. Future studies should use more organizations from public and private sectors and larger sample sizes to enhance generalizability, one of the bedrock of science.

\section{Conclusion}

Based on the findings in this study, a few conclusions can be made. From the results indicated in this study, organizational-based self-esteem plays an essential role in an employee's decision to leave or stay with the organization. The same was also observed for organizational identification and the determination of employees to go or stay with the organization. The effect size for both relationships was meaningful. Organizational trust also mediated the observed relationship between the predictor and criterion variables. These findings led to the following conclusion: to keep employees in the organization, human resources management (HRM) needs to foster trust, build a practice that will promote identification and attachment, and enhance the organizationemployee relationship.

Funding: This research received no external funding.

Acknowledgment:We acknowledge the organizations and employees who participated in this study.

Conflict of interest: The authors declare no conflict of interest.

\section{References}

Akhigbe, O. M., \& Sunday, P. I. (2017). Organizational trust and workplace deviance in higher institutions in River State. International Journal of Managerial Studies and Research, 5(10), 48-62. https://doi.org/10.20431/2349-0349.0510005

Alajmi, S. (2016). Linking psychological empowerment to job satisfaction and organizational commitment: investigating the mediating effect of organizational trust. International Journal of Business and Management, 11(10), 120-140. https://doi.org/10.5539/ijbm.v11n10p120

Aryee, S., Budhwar, P.S., Chen, Z. X. (2002). Trust as a mediator of the relationship between organizational justice and work outcomes: Test of social exchange model. Journal of Organizational Behaviour, 23(3), $267-$ 285.

Ashford, S.J., Lee, C., \& Bobko, P. (1989). Content, cause, and consequences of job insecurity: A theory-based measureand substantive test. Academic Management Journal, 32, 803-829.

Ashforth, B. E., \& Mael, F. (1989). Social identity and the organization. Academy of Management Review, 14, 20 39.

Baghini, B. Z., Pourkiani, M., \& Abbasi, F. B. (2014). The relationship between organizational trust and organizational deviant behaviour of staff in Rafaah bank branches in kerman city. Arabian Journal of Business and Management Reviews, 3(11), 124-133.

Balkan, M.O., Serin, E.A., \& Soran, S., (2014). The relationship between trust, turnover intentions and emotions: An application. European Scientific Journal, 10(2), 73-85.

Bayhan K. P., Metin C, S., \& Tayfur E. O. (2016). The mediating effect of organizational trust on the link between the areas of work life and emotional exhaustion. Educational Sciences: Theory and Practice, 16, 19471980. https://doi.org/10.12738/estp.2016.6.0068

Bhattacharya, R., Devinney, T. M., \& Pillutla, M. M. (1998). A formal model of trust based on outcomes. Academy of Management Review, 23, 459-472.

Blau, P. (1964). Exchange and Power in Social Life. New York: John Wiley \& Sons.

Bowden, T. (2002). An investigation into psychological predictors of work family conflict and turnover intention in an organizational context. [Working Paper]. University of Kent, Canterbury, United Kingdom. 
Carmeli, A., Gilat, G., \& Waldman, D.A. (2007). The role of perceived organisational performance in organisational identification, adjustment and job performance. Journal Management Studies, 44, 972-992.

Carson, K. D., Carson, P. P., Yallapragada, R., Langford, H., \& Roe, W. (1998). Emergency medical technicians: Is career satisfaction within their control? Hospital Topics: Research and Perspectives on Healthcare, 76(1), 1519.

Celik, M., Turunc, O., \& Begenirbas, M. (2011). The role of organizational trust, burnout and interpersonal deviance for achieving organizational performance. International Journal of Business and Management Studies, 3(2), 179-189.

Chan, S. C. H., Huang, X., Snape, E., \& Lam, C.K. (2013). The Janus face of paternalistic leaders: Authoritarianism, benevolence, subordinates' organization-based self-esteem, and performance. Journal of Organizational Behaviour, 34, 108-128. https://doi.org/10.1002/job.1797

Chhetri, P. (2014). The role of cognitive and affective trust in the relationship between organizational justice and organizational citizenship behaviour: A conceptual framework. Verslas: TeorijalrPraktika, 15(2), 170-178. https://doi.org/10.3846/btp.2014.17

Chi, S., Friedman, R., \& Lo, H. (2010). The Downside of Organizational Identification: Collective Shame and Turnover during Organizational Mistakes [paper presentation]. International Association of Conflict Management23rdAnnual conference. Boston, Massachusetts, united states.

Chiedu, C. K., Long, C. S., \& Ashar, H. B. (2017). The relationship among job satisfaction, organizational commitment and employee turnover intention at Unilever Corporation in Nigeria. European Journal of Multidisciplinary Study, 2(5), 370-383.

Cohen, J (1988). Statistical power analysis for the behavioural science(2nd ed.). Lawrence Erlbaum: Hillsdale, NJ.

Cole, M.S., \& Bruch, H. (2006). Organizational identity strength, identification, and commitment and their relationships to turnover intention: Does organizational hierarchy matter? Journal of Organizational Behaviour, 27, 585-605. https://doi.org/10.1002/job.378

Cook, J., \& Wall, T. (1980). New work attitude measures of trust, organizational commitment and personal neednon-fulfilment. Journal of Occupational Psychology, 53, 39-52.

Cotton, J. L., \& Tuttle, J. M. (1986). Employee turnover: A meta-analysis and review with implication for research. The Academy of Management Research, 11(1), 55-70.

Davis, J. H., Schoorman, F. D., Mayer, R. C., \& Tan, H. H. (2000). The trusted general manager and business unit performance: Empirical evidence of a competitive advantage. Strategic Management Journal, 21(5), 563-576.

Dutton, J. E., Dukerich, J. M., \& Harquail, C. V. (1994). Organizational images and member identification. Administrative Science Quarterly, 39, 239-263.

Feldt, L. S., \& Kim, S. (2008). A comparison of tests for equality of two or more independent alpha coefficients. Journal of Educational Measurement, 45(2), 179-193.

Field, A. (2013). Discovering statistics using IBM SPSS Statistic (4th ed.) London: Sage Publications.

Gambetta, D. (1988). Trust: Making and breaking cooperative relations. New York: Basil Blackwell.

Gardner, D. G., \& Pierce, J. L. (2001). Self-esteem and self-efficacy within the organizational context: A replication. Journal of Management Systems, 13(4): 31-48.

Gardner, D. G., \& Pierce, J. L. (2011). A question of false self-esteem: Organization-based self-esteem and narcissism in organizational contexts. Journal of Managerial Psychology, 26, 682-699. http://doi.org/10.1108/02683941111181770

Ghasemi, A., \&Zahediasl, S. (2012). Normality test for statistical analysis: A guide for non-statisticians. International Journal of Endocrinology and Metabolism, 10(2), 486-489.

Griritli, H. (2015). Organizational identification and turnover intention of employees in the Turkish construction industry [Conference session]. 13th Annual Conference of the International Council for Research and Innovation in Building and Construction, London South Bank University, United Kingdom. 
Hameed, I., Arain, A. G., \& Farooq, O. (2013). Identity-based trust as a mediator of the effects of organizational identification on employee attitudes: An empirical study. International Journal of Management, 30(2), 666677

Hardaningtyas, R. T. (2020). Personal resource and turnover intention among private-sector employees: Does work engagement still matters?JurnallmiahBidangAkuntansidanManajemen, 17(1), 1-18.

Hayes, A. (2013). Introduction to mediation, moderation, and conditional process analysis. New York: Guilford Press.

Howitt, D., \& Cramer, D. (2011). Introduction to SPSS Statistics in psychology for version 19 and earlier. (5th ed.). Pearson: New York, NY, USA.

Iqbal, Q., \& Ahmad, B. (2016).Organizational justice, trust and organizational commitment in banking sector of Pakistan. Journal of Applied Economics and Business, 4(1), 26-43.

Kark, R., \& Shamir, B. (2002). Untangling the relationships between transformational leadership and followers' identification, dependence and empowerment [Working paper]. University of Michigan, Ann Arbor.

Kaur, B., \& Mohindru, P. D. (2013). Antecedents of turnover intentions: A literature review. Global Journal of Management and Business Review, 3(10), 1219-1230.

Kim, S. W., Price, J. L., Mueller, C. W., \& Watson, T. W. (1996). The determinant of career intent among physicians at a US Air Force Hospital. Human Relations, 46, 947-976.

Kumar, M., \& Singh, S, (2012). Roles of perceived exchange quality and organisational identification in predicting turnover Intention. IIMB Management Review, 24, 5-15. https://doi.org/10.1016/j.iimb.2011.12.005

Kura, K. M., Shamsudin, F. M., \& Chauhan, A. (2016). Organizational trust as mediator between perceived organizational support and constructive deviance. International Journal of Business and Society, 17(1), 1-18.

Lamsa”, A., \& Pucetaite, R. (2006). Development of organizational trust among employees from a contextualperspective. Business Ethics: A European Review, 15, 130-141.

Lynn, M. R. (1986). Determination and quantification of content validity. Nursing Research, 35, Article 382-5.

MacKenzie, S. B. \& Podsakoff, P. M. (2012). Common method bias in marketing: Causes, mechanisms, and procedural remedies, Journal of Retailing, 88(4) 542-555.

Mael, F., \& Ashforth, B. E. (1992). Alumni and their alma mater: A partial test of the reformulated model of organisational identification. Journal Organizational Behaviour, 13, 103-123. https://doi.org/10.1002/job.4030130202

Mayer, R. C., Davis, J. H., \& Schoorman, F. D. (1995). An integrative model of organizational trust. Academy of Management Review, 20(3), 709-734.

Mbah, S. E., \&Ikemefuna, C. O. (2012). Job satisfaction and employee turnover intention in total Nigeria plc. in Lagos State. International Journal of Humanities and Social Sciences, 2(14), 275-287.

McArthur, D.N. (2007). Construct equivalence in international business research: The first and last of it. Journal of Business Inquiry, 6(1), 28-38.

Meyer, J. P., Stanley, D. J., Herscovitch, L., \& Topolnytsky, L. (2002). Affective, Continuance, and Normative Commitment to the Organization: A Meta-Analysis of Antecedents, Correlates, and Consequences. Journal of Vocational Behaviour, 61(1), 20-52.

Patchen, M. (1970). Participation, Achievement, and Involvement on the Job. Prentice-Hall: Englewood Cli_s, NJ, USA.

Phillips, G. M., \& Hall, R. J. (2001). Perceived organizational support: The mediating role of self-structures [paper presentation]. Annual conference of the Society for Industrial and Organizational Psychology, San Diego, CA.

Pierce L. J., Gardner, G. D., Cummings, L. L., \& Dunham, B. R. (1989). Organisation-based self-esteem: Construct definition, measurement and validation. Academy of Management Journal, 32, 622-648.

Pierce, J. L., \& Gardner, D. G. (2004). Self-esteem within the work and organizational context: A review of the organization-based self-esteem literature. Journal of Management, 30, 591-622. https://doi.org/10.1016/j.jm.2003.10.001 
Podsakoff, P. M., MacKenzie, S. B., Lee, J.-Y. \& Podsakoff, N. P (2003). Common method biases in behavioural research: A critical review of the literature and recommended remedies, Journal of Applied Psychology, 88(5), 879-903.

Pratt, M. G. (1998). To be or not to be: Central questions in organizational identification. In D. A. Whetten \& P. C. Godfrey (Eds.), identity in organizations (pp. 171-207). Thousand Oaks, CA: Sage.

Ran, X., \& Wang, Y. (2010). The influence of trust on counterproductive work behaviour [Paper presentation]. International conference on E-product, E-service and E-entertainment, Xi'an, China.

Riketta, M. (2005). Organizational identification: A meta-analysis. Journal of Vocational Behaviour, 66, 358-384.

Robinson, S. L. (1996). Trust and breach of the psychological contract. Administrative Science Quarterly 41(4), 574599.

Rousseau, D. M. (1998). Why workers still identify with organizations. Journal of Organizational Behaviour, 19, $217-$ 233.

Seo, Y. J., \& Ko, J. W. (2002). Determinant of intent to leave among physicians working at general hospitals after the separation program of prescribing and dispensing. Korean Journal of Health Policy Administration, 12, 68-90. https://doi.org/10.4332/KJHPA.2002.12.4.068

Shaughnessery, J. J., Zechmeister, E. B., \& Zechmester, J. S. (2003). Research Methods in Psychology (6th ed.). McGrill-Hall: Boston, MA, USA.

Siebert, S., Martin, G., Bozic, B., \& Docherty, I. (2015). Looking beyond the factory gates: Towards more pluralist and radical Approaches to intraorganizational trust research. Organization Studies, 36(8), 10331062. https://doi.org/10.1177/0170840615580010

Staehle-Moody, C. M. (1998). Adaptation to organizational change: A study of middle managers' coping styles and their correlates. Dissertation Abstracts International: Section B: The Sciences and Engineering, 59(5-B): 2471.

Steenkamp, J. B. E. M., de Jong, M. G., \& Baumgartner, H. (2010). Socially desirable response tendencies in survey research, Journal of Marketing Research, 47(2), 199-214.

Stengel, M. (1987). Identifikationsbereitschaft, Identifikation, Verbundenheitmiteiner Organisation oderihrenZielen [Readiness for identification, identification with, and commitment to, an organization or its goals]. ZeitschriftfuerArbeits- und Organisations psychologie, 31, 152-166.

Sumanasiri, E. G. T., Ab Yajid, M. S., \& Khatibi, A. (2016).Organization-based self-esteem (OBSE) and its influence on self-perceived employability (SPE) of IT export sector employees in Sri Lanka.European Scientific Journal, 12(14), 124-133.

Tan, H. H., \& Tan, C. S. (2000). Toward the differentiation of trust in supervisor andtrust in organization. Genetic, Social, and General Psychology Monographs, 126(2),241-260.

Tang, T. L., Singer, M. G., \& Roberts, S. (2000). Employees' perceived organizational instrumentality: An examination of the gender differences. Journal of Managerial Psychology, 15(5), 378-406.

Tang, T. L., \& Ibrahim, A. H. S. (1998). Antecedents of organizational citizenship behaviour revisited: Public personnel in the United States and in the Middle East. Public Personnel Management, 27(4), 529-549.

Ugwu, F. O., Onyishi, I. E., \& Rodriguez-Sanchez, A. (2014). Linking organizational trust with employee engagement: The role of psychological empowerment. Personnel Review, 43(3), 377-400. https://doi.org/10.1108/PR-11-2012-0198

Umar, S., \& Ringim K. J. (2015). Psychological contract and employee turnover intention among Nigerian employees in private organizations [conference session]. Management international conference, Portoroz, Slovenia.

Valenti, A., \& Horner, S. V. (2019). Leveraging board talent for innovation strategy. Journal of Business Strategy, 41(1), 11-18. https://doi.org/10.1108/JBS-12-2018-0207

Van Dick, R., Ulrich, W, Jost, S., \& Oliver, C. (2004). The Utility of a Broader Conceptualization of Organisational Identification: Which Aspects Really Matter? Journal of Occupational and Organisational Psychology, 77(2), 171-92. 
Van Dyne, L., \& Pierce, J. L. (2004). Psychological ownership and feelings of possession: three field studies predicting employee attitudes and organizational citizenship behaviour. Journal of Organizational Behaviour, 25, 439-459.

Whitener, E. M., Brodt, S. E., Korsgaard, M. A., \& Werner, J. M. (1998). Managers as initiators of trust: An exchange relationship framework for understanding managerial trustworthy behaviour. Academy of Management Review, 23, 513-530.

Xiong, K., Lin, W., Li, J. C., \& Wang, L. (2016). Employee trust in supervisors and affective commitment: The moderating role of authentic leadership. Psychological Reports, 118(3), 829-848. https://doi.org/10.1177/0033294116644370

Yu, M. C., Mai, Q., Tsai, S. B., \& Dai, Y. (2018). An empirical study on the organizational trust, employeeorganizational relationship and innovative behaviour from the integrated perspective of social exchange and organizational sustainability. Sustainability, 10, Article 864.

Zang, S., \& Liu, Z. (2016). A meta-analysis of the relationship between organizational identification and turnover intention. ActaPsychologicaSinica,

$48(12)$ 1561-1573. https://doi.org/10.3724/SP.J.1041.2016.01561 